\title{
Study of Drinking Water Production in Water Treatment Plant " $X$ " using Hazard Analysis Critical Control Point Method
}

\author{
Meralda Rose Dewi ${ }^{1}$, Nieke Karnaningroem ${ }^{1}$, and Mas Agus Mardyanto ${ }^{1}$
}

\begin{abstract}
Water Treatment Plant (WTP) " $X$ " consists of intake, aerator, pre-sedimentation, coagulation, clearator, filter and reservoir. In the production of drinking water, several problems are encountered that threaten the process. These constraints affect the production target in regard to quality. Minister of Health Regulation No. 492 of 2010 about Requirements for Quality of Drinking Water stated every drinking water provider is obliged to guarantee the drinking water it produces is safe for human health, meeting the quality standards of physical, chemical and biological parameters.

This study used Hazard Analysis Critical Control Point method. Hazard Analysis is an analytical method to identify the presence of hazards and risks in the supply production chain so the control management can be established. The existence of hazards in production process will cause losses in terms of economics and also customer trust. This method reviewed based on laboratory results of water quality and the existing conditions of operational in production process.

The analysis and evaluation of its existing conditions using HACCP method generates information that the biggest source of risk that affects the quality of production is found in the operations of each processing unit and fluctuations of its debit. The corrective actions that can be taken to prevent the occurrence of failures in the production system are improving the performance of the water treatment units, discharge settings according to unit capacity, there must be modification of the flocculation and aeration process, also improvement of workers' insights regarding water quality in accordance with SNI 014852-1998.
\end{abstract}

Keywords-HACCP, Hazard Analysis Critical Control Point, Process, Drinking Water Production, Water Treatment Plant, Organic Content.

\section{INTRODUCTION}

The quality of river water used for raw water is influenced by human activities around it. (Agustiningsih et al, 2012). The more human activity, the greater the burden of pollutants entering the body (Mahyudin et al., 2015). Changes in raw water quality can affect the quality of drinking water that is processed and distributed to the community[1].

To improve water quality, there are many obstacles encountered such as damage to production facilities and

\footnotetext{
${ }^{1}$ Meralda Rose Dewi, Nieke Karnaningroem, and Mas Agus Mardyanto are with Department of Environmental Engineering, Institut Teknologi Sepuluh Nopember, Indonesia. Email: meraldard@gmail.com; n.karnaningroem@gmail.com; mardyanto@enviro.its.ac.id.
}

risk factors that threaten the sustainability of production. To anticipate and minimize the risk of process failure, it is necessary to apply a standard and a strategy so that production targets can be achieved both in quality and quantity. Water quality standards are created to maintain and protect public health as consumers. To achieve this standardization, a comprehensive control and supervision of the drinking water production process is needed, namely using the HACCP method[2].

Hazard Analysis Critical Control Point (HACCP) is an analytical method used to identify hazards that may arise in the chain of a production process and establish a control (critical control point) that is focused on prevention in order to minimize the presence of danger or risk[3].

The benefit of this research is to provide information about risks and ways to deal with hazards that threaten water quality. Its output is in the form of recommendations for the application of HACCP to ensure the safety of water quality so that consumer trust could increases and also guarantees the health of consumers. For those reasons, it is necessary to conduct a study of drinking water production using the HACCP method in Water Treatmen Plant cause it can identify the danger points that occur in a process until it become products that are ready to be consumed, and the production target could be achieved in quality, quantity and continuity.

The scope of this study is evaluation focused on the drinking water production system from raw water treatment to the final product without its distribution system, the aspects used in this study are the technical aspects of each water treatment unit and human resources.

\section{LITERATURE REVIEW}

\section{A. Raw Water Source}

Water sources are water which are above and below the surface of the land, including aquifers, springs, rivers, swamps, lakes, situ, reservoirs, and estuaries (PP No. 82 of 2001). Based on PerMenPU No. 27 of 2016 that raw water for household drinking water is water originating from surface water sources, ground water, rainwater and sea water that meet certain quality standards as raw water for drinking water. 


\section{B. Characteristics of Drinking Water}

According to the Minister of Health in Regulation No. 492 of 2010 that drinking water is safe for health if it meets physical, microbiological, chemical and radioactive requirements. The problem of water quality arises from several properties of water and the content of living things, substances, energies and other components present in the water. Drinking water quality is influenced by raw water quality because raw water quality determines the process in a Drinking Water Treatment Plant[4].

\section{1) Drinking Water Pollution}

The presence of matter which results in water not meeting the quality standard and cannot be used normally is called water pollution[5]. According to Government Regulation No. 20 of 1990 concerning Water Pollution Control that water pollution is defined as the entry of living things, substances, energy, and / or other components into water by human activities so that the water quality drops to a certain level which causes water no longer function according to its designation.

2) Drinking Water Quality Parameters

Based on Minister of Health Regulation No. 492 of 2010, drinking water is safe for health if it meets physical, microbiological, chemical and radioactive requirements according to the required parameters and additional parameters. Required parameters are drinking water quality requirements that must be followed and adhered to by all drinking water factory. As for additional parameters, the regional government can set additional parameters in accordance with the conditions of the quality of the environment in each area. The parameters of drinking water quality regarding drinking water quality standards consist of mandatory parameters listed in the Minister of Health Regulation No.492 of 2010 can be seen in Table 1.

TABLE 1.

MANDATORY PARAMETERS OF DRINKING WATER QUALITY

\begin{tabular}{llcc}
\hline \hline \multicolumn{1}{c}{ Parameter Type } & Units & $\begin{array}{c}\text { Maximum } \\
\text { Allowable Levels }\end{array}$ \\
\hline A & Microbiology Paramaters & & \\
& E. Coli & $\begin{array}{c}\text { Amount Per } \\
100 \mathrm{ml} \mathrm{Sample}\end{array}$ & 0 \\
\hline B & Physical Parameters & & \\
\hline & Turbidity & $\mathrm{NTU}$ & 5 \\
& Total Dissolved Solid (TDS) & $\mathrm{Mg} / \mathrm{L}$ & 500 \\
\hline C & Chemical Parameters & & \\
\hline & Ph & & $6.5-8.5$ \\
& Aluminium & $\mathrm{Mg} / \mathrm{L}$ & 0.2 \\
& Kesadahan & $\mathrm{Mg} / \mathrm{L}$ & 500 \\
& Sisa Klor & $\mathrm{Mg} / / \mathrm{L}$ & 5 \\
\hline \hline
\end{tabular}

The parameters found in Minister of Health Regulation No.492 of 2010 consist of microbiological parameters, physical parameters and chemical parameters. But in this study only the turbidity, e coli and organic matter parameters will be seen. This is adjusted to the conditions of the raw water source.

Turbidity can indicate the condition of sediment in water and the tendency of water to spread light[6]. Organic substances in water can affect changes in physical properties of water, especially the appearance of color, taste, and turbidity (Sutrisno, 2006). Microbiological examination focused on examining the presence of Coliform bacterial pathogens originating from faeces, which is E. Coli. E. Coli bacteria in water comes from contamination of animal and human faeces[7]. E. Coli is most widely used as an indicator of sanitation because water contaminated with fecal bacteria could cause diseases so it is not suitable for consumption[8].

\section{Drinking Water Treatment Process in WTP}

In addition to raw water, the quality of drinking water is also influenced by the processing carried out in WTP [4]. Basically the methods used for water treatment from various sources and for various purposes are distinguished as physical processing (operating units), chemical processing (unit processing) and biological processing[9]. The processing process in this study is the intake, aerator, pre-sedimentation, coagulation, clearator, filter and reservoir.

\section{Hazard Analysis Critical Control Point}

Hazard Analysis Critical Control Point or commonly called HACCP is a quality assurance system that is based on the awareness that hazards will arise at various points or stages of production so that control measures can be taken to control and minimize the occurrence of these hazards. The main key to HACCP is in anticipating hazards and identifying monitoring points that prioritize preventive actions rather than relying on final product testing [10].

HACCP must be carried out on a systematic scientific basis to ensure the quality of a product is safe from physical, chemical and microbiological hazards[11]. The application of HACCP needs to be implemented in flexible way, where appropriate changes are adjusted to take into account the nature and size of the operation[2].

1) Principle of $\mathrm{HACCP}$

Based on BSN (1998), the application of HACCP principles consists of tasks or stages as follows:

a. Principle 1: Hazard analysis

Hazard Analysis is carried out when a process is in progress, which are analysis of raw materials and each process in the production chain. The danger was significant if it can be harmful to consumers. According to Sudarmaji (2015), Hazards are all aspects from the production chain that are unacceptable because they could cause problems that can affect the quality of product.

b. Principle 2: Identification of CCP (Critical Control Point)

CCP is an important step to prevent or eradicate the hazards. So the CCP related to the hazards of control measures which can be applied to achieve a safe point. 
According to [12], critical control points can be carried out in terms of raw materials, locations, procedures or processing. To identify the CCP, the entire production chain can be assessed using the fishbone and failure mode and effect analysis methods.

c. Principle 3 : Establish critical limits for each CCP

Critical limits are safety limits that must be fulfilled for each control measure carried out in the CCP step. Critical limits are the criteria that distinguish between safety and the possibility of being unsafe. Determination of critical limits based on legislation, safety standards, and values that have been scientifically tested.

d. Principle 4 : Establish a monitoring system

Monitoring is the action needed to ensure that the process is controlled and runs within the specified critical limits. Monitoring is carried out through observation. All parties that have responsibility for monitoring must be trained and have a clear understanding.

\section{e. Principle 5 : Establish corrective actions}

Corrective actions must be properly defined to ensure the CCP that are out of control can be controlled and further deviations can be prevented.

This principle must be carried out continuously, meaning that it does not stop after one stage of analysis is carried out and the hazard must be resolved until the end[13].

2) Advantages of $\mathrm{HACCP}$

Some of the benefits that can be obtained by the government, agencies and consumers from the application of HACCP[12]:

a) Can be applied to all aspects of processing, including biological, chemical and physical hazards at every stage of the production chain, from raw materials to final products.

b) Provide alternative activities that can be done to prevent the occurrence of danger before reaching consumers.

c) HACCP as a complementary system of inspection by the government so that supervision could be optimal.

d) Can minimize health risks related to consumption.

e) Can increase consumer trust in safety of the results.

f) Can save production and operational costs, improve product quality and reduce defects in products[14].

\section{Methodology}

This study includes literature studies from various literature, journals, and articles. In addition, field studies were also conducted to determine the existing conditions of the processing system by carrying out monitoring and interviews with the internal parties of WTP regarding the production process. In this study, which examined is a problem in the processing is the process of intake, aerator, prasedimentasi, coagulation, clearator, filter and reservoir. Laboratory analysis was carried out as a preliminary study of the initial characteristics of water in each unit in the WTP. Water quality research is carried out for 5 days during the operational hours of WTP. The sampling point is the intake and outlet of each unit in WTP. The parameters tested in this study were turbidity, organic matter and E. coli. Turbidity analysis was carried out using a turbidimeter. Analysis of organic matter was carried out using the permanganate titration method SNI 06-6989.222004. Analysis of E. coli was carried out by multi-tube fermentation method.

In addition to the primary data above, secondary data is also needed as a comparison and additional information. Secondary data is data about the performance of the production process of each processing unit that is obtained from relevant sources that the results can be accounted for, such as water quality data were tested by WTP, processing flow diagram, data on raw water and organizational structure. After obtaining primary and secondary data that supports the technical and environmental aspects of the study of this method, data cultivation can be done as a consideration in determining the critical control points and controls on the HACCP plan..

\section{RESULT AND DISCUSSION}

\section{A. Existing Conditions of WTP " $X$ "}

In this study, there were 7 sampling points which were taken from each outlet unit in WTP "X" which are intake, aerator, pre-sedimentation, coagulation, clearator, filter and reservoir outlets. The WTP " $\mathrm{X}$ " processing discharge is $2200 \mathrm{~L} / \mathrm{sec}$. The raw water used comes from the River.

1) Analysis of Turbidity

Based on Minister of Health Regulation No. 492 of 2010 concerning Drinking Water Quality Requirements, turbidity is a physical parameter of drinking water quality with a maximum limit of 5 NTU. Turbidity analysis was carried out using a turbidimeter. The results of the analysis can be seen in Table 2 .

TABLE 2 .

RESULTS OF TURBIDITY ANALYSIS

\begin{tabular}{ccccccc}
\hline \hline Intake & Aerator & Prased & Coagulation & Clearator & Filter & Reservoir \\
\hline 110 & 140 & 60 & 80 & 6,9 & 1,2 & 1,2 \\
140 & 150 & 100 & 110 & 7,4 & 2,9 & 2,5 \\
171 & 201 & 145 & 226 & 10,4 & 3,2 & 3 \\
82 & 133 & 84,9 & 104 & 6,4 & 2,19 & 1,9 \\
395 & 477 & 339 & 405 & 4,89 & 1,32 & 1,1 \\
\hline \hline
\end{tabular}

Based on the results of the sampling, the turbidity of raw water at the intake fluctuated with the lowest turbidity of 82 NTU and the highest at 395 NTU. The turbidity of raw water at the intake is quite high because of the rain which causes the river's water debit to be large so that there is a sediment that goes dissolved. Turbidity in the aerator also fluctuates with the result that turbidity is higher than raw water due to the aeration process. According to [15], that turbidity in the aeration unit does not decrease because aeration does not function to decreasing the turbidity but to increase oxygen dissolved in water. Turbidity in prasedimentationuntil the reservoir fluctuates and the final 
production of drinking water for five days has met the quality standard.

This are the results of calculating efficiency for turbidity parameters using the formula:

$$
\%=\frac{\text { influen }- \text { efluen }}{\text { influen }} \times 100 \%
$$

TABLE 3 .

REMOVAL TURBIDITY IN PRASEDIMENTATION

\begin{tabular}{cccc}
\hline \hline Day & Aerator & Prasedimentation & Removal (\%) \\
\hline 1 & 140 & 60 & 57,1 \\
2 & 150 & 100 & 33,3 \\
3 & 201 & 145 & 27,9 \\
4 & 133 & 84,9 & 36,2 \\
5 & 477 & 339 & 28,9 \\
\hline \hline
\end{tabular}

From the table above it is known that turbidity removal of prasedimentation units tends to fluctuate in the range of $27 \%$ to $57 \%$. According to Metcalf-Eddy, the design criteria for turbidity efficiency in prasedimentation processing are $65-70 \%$. This shows that prasedimentationhas not run optimally.

TABLE 4.

TURBIDITY REMOVAL IN FILTER

\begin{tabular}{cccc}
\hline \hline Day & Clearator & Filter & Removal (\%) \\
\hline 1 & 6,9 & 1,2 & 82,6 \\
2 & 7,4 & 2,9 & 60,8 \\
3 & 10,4 & 3,2 & 69,2 \\
4 & 6,4 & 2,19 & 65,8 \\
5 & 4,89 & 1,32 & 73,0 \\
\hline \hline
\end{tabular}

According to [16], that the design criteria for filter efficiency with the type of Rapid Sand Filter is 90-98\%. Judging from the results of the above calculations, the filter performance is not optimal even though the effluent that comes out has met the quality standard. This can be affected by the washing of media or media that have never been replaced.

\section{2) Analysis of Organic Matter}

Allowance of organic matter in the process of WTP processing occurs in the process of aeration, coagulation and disinfection[17]. This analysis is carried out using the principle of titration to obtain the permanganate value. The results of the analysis can be seen in Table 5 .

TABEL 5.

RESULTS OF ORGANIC MATTER ANALYSIS

\begin{tabular}{rrrrrrr}
\hline \hline Intake & Aerator & Prased & Coagulation & Clearator & Filter & Reservoir \\
\hline 29,2 & 28,1 & 25,6 & 16,2 & 11,4 & 10,5 & 9,1 \\
30,3 & 29,2 & 24,6 & 17,5 & 12,3 & 11,1 & 9,5 \\
31,6 & 30,3 & 21,5 & 19,0 & 11,4 & 10,7 & 8,5 \\
$\mathbf{3 2 , 9}$ & $\mathbf{3 1 , 6}$ & $\mathbf{2 9 , 1}$ & $\mathbf{1 2 , 6}$ & $\mathbf{1 5 , 0}$ & $\mathbf{1 3 , 9}$ & $\mathbf{1 1 , 4}$ \\
$\mathbf{4 3 , 0}$ & $\mathbf{4 1 , 7}$ & $\mathbf{3 1 , 6}$ & $\mathbf{2 2 , 8}$ & $\mathbf{2 3 , 1}$ & $\mathbf{1 5 , 2}$ & $\mathbf{1 2 , 0}$ \\
\hline \hline
\end{tabular}

Based on Minister of Health Regulation No. 492 of 2010 concerning Drinking Water Quality Requirements, the quality standard for organic matter is $10 \mathrm{mg} / \mathrm{L}$. Based on the results of the above analysis, there are final production results exceeding the quality standard, $11.4 \mathrm{mg} / \mathrm{L}$ and 12 $\mathrm{mg} / \mathrm{L}$.

This is also supported by an increasing turbidity on the same day. So, the hypothesis of this event is due to the existence of rain on a fairly long and also the aerator in the WTP does not work optimally.

3) Analysis of E. Coli

The disinfection process used by this WTP is chlorination. Chlorination is the application of chlorine gas to water. E. Coli analysis was carried out by multi-tube fermentation method based on Standard Methods. The results of the analysis can be seen in Table 6 .

TABLE 6.

RESULTS OF E.COLI PARAMETER ANALYSIS

\begin{tabular}{ccccccc}
\hline \hline Intake & Aerator & Prased & Coagulation & Clearator & Filter & Reservoir \\
\hline 6000 & 17000 & 4000 & 6000 & 0 & 170 & 0 \\
2000 & 2000 & 4000 & 4000 & 40 & 14 & 0 \\
14000 & 2000 & 9000 & 17000 & 4000 & 7000 & 0 \\
17000 & 4000 & 140000 & 4000 & 4000 & 4000 & 0 \\
9000 & 0 & 17000 & 2000 & 90 & 2 & 0 \\
\hline \hline
\end{tabular}

The results obtained from the test are that processed water has met the quality standards of Minister of Health Regulation No. 492 of 2010 concerning Drinking Water Quality Requirements that is 0 . Although it is known that there are sufficiently high fluctuations in the prasedimentationunit, filtration and disinfection units can reduce these bacteria.

\section{B. Principle 1: Hazard analysis}

Hazard analysis is obtained from field observations of the system and processing units regarding each of the factors that cause the processing unit not to run optimally and treated water has the risk of not meeting the Minister of Health Regulation No. 492 of 2010 concerning the Quality of Drinking Water. Apart from observation, this was obtained based on the results of laboratory analysis and the results of the questionnaire as well as interviews with professional judgment, namely the production manager, supervisor, quality control staff, and operator.

Risk and hazard analysis in the production process chain can be carried out using the FMEA method to obtain control priorities. FMEA can be used to find the biggest risk that causes the decline in production water quality [17]. Types of failure that have significant and high-risk effects are included as critical control points. Significant and high-risk influences here are indicated by the acquisition of a score above 20 . The value of 1 is not used because it indicates that failure never occurs so the risk of danger does not have the potential to emerge. While values above 20 indicate failure can disrupt the production process so that it affects the characteristics or quality of production 
directly, such as the content of organic matter and turbidity that exceeds the quality standard[18].

The following are the types of failures and their identified hazards:

1. The lack of training regarding drinking water quality management system in accordance with SNI 01-48521998 which can cause system failure due to human resources as the processing executor does not understand well the management of drinking water quality.

2. There is no strainer in the water withdrawal pipe from the intake to the raw water pump, so the macrodebric waste particles that pass through coarse filtration or the barscreen can enter until the processing unit.

3. Gradient Speed in the flocculation process exceeds the design criteria so that it poses a danger that floc is not formed optimally and precipitation cannot occur.

4. The filter media has never been replaced so that it can cause danger, such as turbidity and organic matter will not drop.

5. The gas transfer speed at the existing condition of the aerator unit is insufficient and does not comply with the design criteria. Hazards that can arise from such failures are organic substances in the water can not be decomposed completely and can trigger Trihalometan in the disinfection process.

6. Reynold numbers and froude numbers of prasedimentationunits of existing conditions do not match the existing design criteria. So that the flow in the prasedimentationunit is turbulent and danger can arise, which the efficiency of removal of turbidity won't be optimal.

7. The absence of a backup pump in the WTP will affect the quality, quantity and continuity of water in the event of damage or maintenance.

8. Water quality testing is not carried out in all outlet units so that the danger that can arise is the efficiency of removal of organic substances after the aeration process cannot be known and the quality can be disrupted.

9. Not implementing the jar test routinely so that the hazards that can arise is chemicals dosage are not optimum so that floc will not be formed optimally, and turbidity also organic substances can not be dropped.

10. The workers incomprehension regarding the operational unit according to ISO9001 derivative will have a major impact on treatment processes that affect water quality. The quality of product can be decreased if there is a procedure or process that is not implemented properly by the workers.

11. Drainage of prasedimentation which is not in accordance with the type of unit. Drainage of prasedimentation which should use a scrapper, but using manual methods due to damaged scrapper conditions will cause the mud to not be wasted optimally.
12. Raw water discharge in WTPs has fluctuations which are largely influenced by the season. As a result of the fluctuating raw water discharge can affect the optimal stay time of a unit. If the detention time is not optimal, it will affect the effectiveness of processing and the quality of water produced.

13. The detention time of prasedimentation which is not in accordance with the conditions of the discharge that enters the treatment will result in not optimal deposition in the pre-sedimentation unit so as not to reduce turbidity.

\section{Principles 2 and 3: Determination of Critical Control Points and Critical Limits}

A critical control point or also called a Critical Control Point (CCP) is a point, procedure or step that has been missed from control resulting in the emergence of risks to drinking water security[19].

Critical limit is a value or criterion that separates between acceptable conditions and those that cannot be accepted for each critical control point. Critical limits are set to ensure that critical control points can be controlled properly[19]. Critical limits must not be violated or exceeded to avoid loss of control in an effort to repair. Determination of critical limits based on legislation, safety standards, and values that have been scientifically tested[12].

Based on the existing hazards and applicable rules, the critical control points and critical limits can be determined which can be seen in Table 7 .

\section{Principles 4 and 5: Determination of Monitoring and Corrective Action Systems}

In the final stage the HACCP method, there are principle 4 and 5. Principle 4 is the determination of the monitoring system. Based on SNI 01-14852-1998, monitoring is scheduled observation activities of each critical control point compared to the critical limit. Monitoring procedures serve to ensure critical control points in controlled conditions and prevent failures from occurring. If the results of monitoring the CCP show a tendency to lose control (failure) then the process can be adjusted with monitoring. Monitoring must be carried out by people who are knowledgeable and authorized to carry out the necessary corrective actions.

Principle 5 is the determination of corrective actions for each hazard identified by failure. Corrective actions are carried out to deal with existing hazards or failures so that they do not reach consumers and become a dangerous condition for consumers' health[19]. The determination of the monitoring system can be seen in Table 8 .

Here are corrective actions that can be implemented for each type of failure:

1. Held a training about drinking water quality management systems that are in accordance with SNI 01-4852-1998 every once a year followed by all staff of the WTP. 
2. Installation of strainer on the water collection pipe so that the waste does not enter the processing unit and also cleaning the screen and balancing wells every two hours.

3. Replacement of filter media every 3 years or when the media has saturated which is characterized by water quality exceeding the quality standard.

4. Addition of diffusion aerator.

5. The detention time must match the incoming debit and design criteria and drain the pre-sedimentation unit routinely and optimally.

6. Add a backup pump

7. Implementation of testing of organic substances on the aerator effluent regularly every two hours.
8. The implementation of the jar test is conducted every two hours.

9. Add training for staff/workers along with competency tests about unit operations and water quality.

10. Repairing the scraper so that the depletion of presedimentation is optimal.

11. Optimalize the pump and valve setting.

12. The detention time in accordance with debit processing, and still in the range of design criteria that is 1-3 hours, also performed with the optimal depletion.

Processing discharge must be in accordance with the unit's design capacity.

TABLE 7.

CRITICAL CONTROL POINTS AND CRITICAL LIMITS

\begin{tabular}{|c|c|c|c|c|}
\hline Type of failure & $\begin{array}{l}\text { Hazards Identified } \\
\text { from Failure }\end{array}$ & $\begin{array}{l}\text { Critical Control } \\
\text { Point }\end{array}$ & Critical Limits & Reference \\
\hline $\begin{array}{l}\text { Training about Quality } \\
\text { Management of } \\
\text { Drinking Water System } \\
\text { in accordance with SNI } \\
01-4852-1998\end{array}$ & $\begin{array}{l}\text { Failure in the } \\
\text { production system }\end{array}$ & $\begin{array}{l}\text { Number of quality } \\
\text { management training }\end{array}$ & $\begin{array}{l}\text { Training at least } \\
\text { once a year }\end{array}$ & $\begin{array}{l}\text { ISO } 22000 \text { and SNI 01-4852-1998 about Hazard } \\
\text { Analysis Systems and Critical Point Control } \\
\text { (HACCP) and guidelines for its application }\end{array}$ \\
\hline $\begin{array}{l}\text { Strainers availability in } \\
\text { Water Retrieval Pipes }\end{array}$ & $\begin{array}{l}\text { Macrodebric particles } \\
\text { pass to the processing } \\
\text { stage }\end{array}$ & Macrodebric particles & $\begin{array}{l}\text { Screen cleaning } \\
\text { and strainer } \\
\text { installation }\end{array}$ & $\begin{array}{l}\text { Minister of Public Works Regulation No. } 26 \text { of } \\
2014 \text { about Standard Operating Procedures for the } \\
\text { Management of Drinking Water Supply Systems }\end{array}$ \\
\hline $\begin{array}{l}\text { Gradien Speed in } \\
\text { Floculation }\end{array}$ & $\begin{array}{l}\text { Floc is not formed } \\
\text { optimally and } \\
\text { precipitation cannot } \\
\text { occur. }\end{array}$ & $\begin{array}{c}\text { Turbidity in } \\
\text { Clearator's Efluen }\end{array}$ & $7 \mathrm{NTU}$ & WTP Regulation (IK-5.4.1-2) \\
\hline $\begin{array}{l}\text { Replacement of Filter } \\
\text { Media }\end{array}$ & $\begin{array}{l}\text { Cannot reduce turbidity } \\
\text { and organic matter }\end{array}$ & $\begin{array}{c}\text { Turbidity } \\
\text { Organic matter } \\
\text { Period of the media } \\
\text { usage }\end{array}$ & $\begin{array}{l}\leq 5 \mathrm{NTU} \\
\leq 10 \mathrm{mg} / \mathrm{L} \\
3 \text { years }\end{array}$ & $\begin{array}{l}\text { Minister of Health Regulation No. } 492 \text { of } 2010 \\
\text { Minister of Health Regulation No. } 492 \text { of } 2010 \\
\text { EPA Water Treatment Manual for Filtration }\end{array}$ \\
\hline $\begin{array}{l}\text { Reynold (Nre) and } \\
\text { Froude (Nfr) Number of } \\
\text { Pre-sedimentation Units }\end{array}$ & $\begin{array}{l}\text { Efficiency removal of } \\
\text { turbidity is not optimal } \\
\text { due to turbulent } \\
\text { conditions }\end{array}$ & $\begin{array}{l}\text { Efficiency removal of } \\
\text { turbidity }\end{array}$ & $65-70 \%$ & Metcalff and Eddie \\
\hline $\begin{array}{l}\text { Availability of Backup } \\
\text { Pumps }\end{array}$ & $\begin{array}{l}\text { Disturbances in the } \\
\text { quality, quantity and } \\
\text { continuity of the raw } \\
\text { water and water } \\
\text { production }\end{array}$ & Processing discharge & $\begin{array}{l}2200 \mathrm{~L} / \mathrm{sec} \text { and } \\
\text { installation of a } \\
\text { backup pump }\end{array}$ & $\begin{array}{l}\text { WTP Capacity and Minister of Public Works } \\
\text { Regulation No. } 26 \text { of } 2014 \text { about Standard } \\
\text { Operating Procedures for the Management of } \\
\text { Drinking Water Supply Systems }\end{array}$ \\
\hline Worker Knowledge & Quality of production & Number of training & Once in three- & ISO 9001 \\
\hline
\end{tabular}




\begin{tabular}{|c|c|c|c|c|}
\hline $\begin{array}{l}\text { related to Unit } \\
\text { Operations in accordance } \\
\text { with ISO } 9001 \text { Rules }\end{array}$ & decreases & related to operations & $\begin{array}{l}\text { month training for } \\
\text { operators }\end{array}$ & \\
\hline $\begin{array}{l}\text { Depletion of Pre- } \\
\text { sedimentation }\end{array}$ & $\begin{array}{l}\text { The surface area is } \\
\text { reduced due to the } \\
\text { remaining sludge in the } \\
\text { pre-sedimentation unit }\end{array}$ & $\begin{array}{l}\text { Drain with a scraper } \\
\text { on schedule }\end{array}$ & $12-24$ hours & $\begin{array}{l}\text { SNI 6774: } 2008 \text { about Procedures for Planning the } \\
\text { WTP Unit }\end{array}$ \\
\hline $\begin{array}{l}\text { Raw Water } \\
\text { Debit/Discharge }\end{array}$ & $\begin{array}{l}\text { The detention time is } \\
\text { not optimal }\end{array}$ & Detention time & $\begin{array}{l}\text { According to } \\
\text { design criteria of } \\
\text { each units }\end{array}$ & $\begin{array}{c}\text { The DED that in accordance with SNI 6774: } 2008 \\
\text { concerning Procedures for Planning WTP Units and } \\
\text { laboratory data }\end{array}$ \\
\hline $\begin{array}{l}\text { Detention time of Pre- } \\
\text { sedimentation }\end{array}$ & $\begin{array}{c}\text { Cannot reduce turbidity } \\
\text { due to the deposition is } \\
\text { not optimal }\end{array}$ & $\begin{array}{l}\text { Efficiency removal of } \\
\text { turbidity }\end{array}$ & $65-70 \%$ & Metcalff and Eddie \\
\hline
\end{tabular}

TABLE 8.

DETERMINATION OF THE MONITORING SYSTEM

\begin{tabular}{|c|c|c|c|c|c|}
\hline \multirow{2}{*}{$\begin{array}{l}\text { Critical Control } \\
\text { Point }\end{array}$} & \multirow{2}{*}{ Critical Limits } & \multicolumn{4}{|c|}{ Monitoring } \\
\hline & & Parts & Procedures & Frequence & Responsibility \\
\hline $\begin{array}{l}\text { Number of quality } \\
\text { management } \\
\text { training }\end{array}$ & Training at least once a year & $\begin{array}{l}\text { Production Section } \\
\text { of WTP "X" }\end{array}$ & $\begin{array}{l}\text { Monitoring / evaluation of workers and } \\
\text { production based on field conditions, } \\
\text { quality management report documents } \\
\text { and quality achievement }\end{array}$ & Each month & $\begin{array}{l}\text { Production } \\
\text { Manager }\end{array}$ \\
\hline $\begin{array}{l}\text { Macrodebric } \\
\text { particles }\end{array}$ & $\begin{array}{l}\text { Screen cleaning and strainer } \\
\text { installation }\end{array}$ & $\begin{array}{l}\text { Water Retrieval } \\
\text { Pipes and balancing } \\
\text { wells }\end{array}$ & $\begin{array}{l}\text { Observation of water, screen and } \\
\text { balancing well conditions }\end{array}$ & Every hour & $\begin{array}{l}\text { Intake Operator and } \\
\text { supervisor of WTP }\end{array}$ \\
\hline $\begin{array}{l}\text { Turbidity in } \\
\text { Clearator's Efluent }\end{array}$ & $7 \mathrm{NTU}$ & Clearator's Effluent & $\begin{array}{l}\text { Turbidity check use turbidimeters, } \\
\text { Checking the flocculant pipe and } \\
\text { maintain the flocculant dose using jar } \\
\text { test. }\end{array}$ & Every hour & Clearator Operator \\
\hline Turbidity & $\leq 5 \mathrm{NTU}$ & Filtration Unit & $\begin{array}{l}\text { Turbidity check use turbidimeters in } \\
\text { effluents }\end{array}$ & Every hour & Filter Operator \\
\hline Organic matter & $\leq 10 \mathrm{mg} / \mathrm{L}$ & & $\begin{array}{l}\text { Organic matter check use } \\
\text { permanganate titration methods in } \\
\text { effluents }\end{array}$ & $\begin{array}{l}\text { Every two } \\
\text { hours }\end{array}$ & $\begin{array}{l}\text { Laboratory } \\
\text { personnel }\end{array}$ \\
\hline $\begin{array}{l}\text { Period of the media } \\
\text { usage }\end{array}$ & 3 years & & $\begin{array}{l}\text { Visual observation of media color, } \\
\text { volume and thickness. } \\
\text { - Backwash of media }\end{array}$ & Every day & Supervisor of WTP \\
\hline Organic matter & $\begin{array}{l}\text { Removal of organic matter on } \\
\text { cascade aerators } 20-45 \%\end{array}$ & $\begin{array}{l}\text { Influent and effluent } \\
\text { of the Aerator Unit }\end{array}$ & $\begin{array}{l}\text { Organic matter check use } \\
\text { permanganate titration methods }\end{array}$ & $\begin{array}{l}\text { Every two } \\
\text { hours }\end{array}$ & $\begin{array}{l}\text { Laboratory } \\
\text { personnel }\end{array}$ \\
\hline $\begin{array}{l}\text { Efficiency removal } \\
\text { of turbidity }\end{array}$ & $65-70 \%$ & $\begin{array}{l}\text { Influent and effluent } \\
\text { of Pre-sedimentation }\end{array}$ & $\begin{array}{l}\text { Turbidity check use turbidimeters in } \\
\text { effluents }\end{array}$ & Every hour & Control operator \\
\hline $\begin{array}{l}\text { Processing } \\
\text { discharge }\end{array}$ & $\begin{array}{l}2200 \mathrm{~L} / \mathrm{sec} \text { and installation of } \\
\text { a backup pump }\end{array}$ & $\begin{array}{l}\text { After the intake unit } \\
\text { head to the } \\
\text { processing unit }\end{array}$ & $\begin{array}{l}\text { - Water level monitoring. } \\
\text { - Monitoring the pressure, ampere, } \\
\text { voltage, power etc. of the pump. }\end{array}$ & Every hour & Pump operator \\
\hline $\begin{array}{l}\text { Efficiency removal } \\
\text { of Organic matter }\end{array}$ & $\begin{array}{l}\text { Removal of organic matter on } \\
\text { cascade aerators } 20-45 \%\end{array}$ & $\begin{array}{l}\text { Influent and effluent } \\
\text { of the Aerator Unit }\end{array}$ & $\begin{array}{l}\text { Organic matter check use } \\
\text { permanganate titration methods }\end{array}$ & $\begin{array}{l}\text { Every two } \\
\text { hours }\end{array}$ & $\begin{array}{l}\text { Laboratory } \\
\text { personnel }\end{array}$ \\
\hline Quality testing & Tested every two hours & & & & \\
\hline $\begin{array}{l}\text { Implementation of } \\
\text { Jar Test }\end{array}$ & $\begin{array}{l}\text { Best floc formation within } 30 \\
\text { minutes, the implementation } \\
\text { of the jar test every two hours }\end{array}$ & Coagulation Unit & Visual observation of floc formation & Every hour & Clearator Operator \\
\hline $\begin{array}{l}\text { Number of training } \\
\text { related to operations }\end{array}$ & $\begin{array}{l}\text { Once in three-month training } \\
\text { for operators }\end{array}$ & $\begin{array}{l}\text { Drinking water } \\
\text { production unit }\end{array}$ & $\begin{array}{l}\text { Monitoring field operational conditions } \\
\text { and its documents }\end{array}$ & Each month & $\begin{array}{l}\text { Production } \\
\text { Manager }\end{array}$ \\
\hline $\begin{array}{l}\text { Drain with a scraper } \\
\text { on schedule }\end{array}$ & $12-24$ hours & $\begin{array}{l}\text { Pre-sedimentation } \\
\text { Unit }\end{array}$ & Visually monitor of the surface area & $\begin{array}{l}\text { Every } \\
\text { twelve hours }\end{array}$ & Control operator \\
\hline Detention time & $\begin{array}{l}\text { According to design criteria of } \\
\text { each units }\end{array}$ & Effluent of all units & $\begin{array}{l}\text { Pump checking and water quality from } \\
\text { the effluent of each unit }\end{array}$ & Every hour & $\begin{array}{l}\text { Control operator, } \\
\text { Laboratory } \\
\text { personnel }\end{array}$ \\
\hline $\begin{array}{l}\text { Efficiency removal } \\
\text { of turbidity }\end{array}$ & $65-70 \%$ & $\begin{array}{l}\text { Influent and effluent } \\
\text { of Pre-sedimentation }\end{array}$ & $\begin{array}{l}\text { Turbidity check in water use } \\
\text { turbidimeters in effluents }\end{array}$ & Every hour & Control operator \\
\hline
\end{tabular}




\section{CONCLUSION}

From the results of the research and analysis carried out, it can be concluded as follows:

1. Evaluation of the existing condition in WTP "X", which can be reviewed using HACCP management plan, are that the quality of raw water does not meet the water quality standard for class II in PP No. 82 of 2001, organic matter in reservoir outlet does not meet the quality standards of Minister of Health Regulation No. 492 of 2010, turbidity in clearator outlet does not meet the regulation in WTP "X", no strainer on the intake pipe, no spare pump, the speed gradient in the flocculation process is not in accordance with the design criteria, the gas transfer speed is not optimal, does not routinely carry out a jar test and does not replace the filter media.

2. The water quality management plan using the HACCP method that can be applied to the production and human resource systems in the WTP "X" are focused on improving the performance of water treatment units, discharge in processing must be in accordance with the unit capacity, there must be modifications on flocculation and aeration process in order to make the processing runs optimally, and increasing the workers' insights regarding water quality with training according to SNI 01-4852-1998.

\section{ACKNOWLEDGEMENT}

Thank you to various parties who have helped the fluency of researchers in retrieving data so that this research can run smoothly.

\section{REFERENCES}

[1] E. B. Sasongko, E. Widyastuti, and R. E. Priyono, "Kajian kualitas air dan penggunaan sumur gali oleh masyarakat disekitar sungai kaliyasa kabupaten cilacap," J. Ilmu Lingkung., vol. 12 , no. 2, pp. 72-82, Oct. 2014

[2] L. Trisnawati, "Perancangan dan Implementasi Hazard Analysis Critical Point (HACCP) Plan Produk Air Minum Dalam Kemasan (AMDK) (Studi Kasus Di PT. Agritech GLOBAL CEMERLANG, Bogor)," Institut Pertanian Bogor, 2008.
[3] T. Muhandri and K. D., Sistem Jaminan Mutu Industri Pangan. Bogor: IPB Press, 2008.

[4] Y. Wahyono, R. Yudhastuti, and S. Keman, "Pengaruh pengolahan dan pendistribusian terhadap kualitas air pelanggan PDAM Mojokerto," J. Kesehat. Lingkung., vol. 3, no. 2, pp. 171 $-182,2007$.

[5] F. F. Awaludin, "Permasalahan Pencemaran dan Penyediaan Air Bersih di Perkotaan dan Pedesaan.” 2015.

[6] A. Gafur, A. D. Kartini, and R. Rahman, "Studi kualitas fisik kimia dan biologis pada air minum dalam kemasan berbagai merek yang beredar di Kota Makassar tahun 2016," pp. 37-46, 2017.

[7] R. Haribi and K. Yusron, "Pemeriksaan escherichia coli pada air bak wudhlu 10 masjid di Kecamatan Tlogosari Semarang," $J$. Kesehat., vol. 3, no. 1, pp. 21-26, 2010.

[8] A. Prayitno, "Uji Bakteriologi Air Baku dan Air Siap Konsumsi dari PDAM Surakarta Ditinjau dari Jumlah Bakteri Coliform," Universitas Muhammadiyah, 2009.

[9] B. Budiyono and S. Sumardiono, Teknik Pengolahan Air. Yogyakarta: Graha Ilmu, 2013.

[10] L. M. Cartwright and D. Latifah, "Hazard Analysis Critical Control Point (HACCP) sebagai model kendali dan penjaminan mutu produksi pangan," Innov. Vocat. Technol. Educ., vol. 6 , no. 2, Apr. 2017.

[11] M. L. Dewi, "Evaluasi Bahaya Mikrobiologi pada Ayam Goreng Laos meliputi Prinsip-prinsip HACCP di Instalasi Gizi RS PKU Muhammadiyah Surakarta.," Universitas Muhammadiyah, 2015.

[12] S. Sudarmaji, "Analisis bahaya dan pengendalian titik kritis (Hazard Analysis Critical Control Point)," J. Kesehat. Lingkung., vol. 1, no. 2, pp. 183-190, 2015.

[13] H. Thaheer, Sistem Manajemen HACCP (Hazard Analysis Critical Point). Jakarta: PT. Bumi Aksara, 2005.

[14] M. S. Hilman and Z. F. Ikatrinasari, "Faktor-faktor yang mempengaruhi efektifitas penerapan sistem HACCP," J. Stand. vol. 16, no. 3, p. 234, Nov. 2014.

[15] I. M. Utami, "Analisis Dampak Lingkungan Proses Pengolahan Air di IPAM ' $\mathrm{X}$ ' dengan Menggunakan Metode Life Cycle Assessment (LCA)," Institut Teknologi Sepuluh Nopember, 2019.

[16] A. Masduqi and A. Abdu F., Operasi dan Proses Pengolahan Air. Surabaya: ITS Press, 2012

[17] N. Fitrianti, "Analisis Penurunan Kualitas Air Produksi Instalasi Pengolahan Air Minum (IPAM) X dengan Metode Failure Mode And Effect Analysis (FMEA)," Institut Teknologi Sepuluh Nopember, 2016.

[18] A. . Daulay, "Karakteristik Sedimen Di Perairan Sungai Carang Kota Rebah Kota Tanjungpinang Provinsi Kepulauan Riau," Univ. Marit. Raja Ali Haji, 2014

[19] F. Hassan, "Kajian Penerapan Sistem Hazard Analysis Critical Control Point (HACCP) di IPAM Porong PDAM Deltra Tirta Sidoarjo," Institut Teknologi Sepuluh Nopember, 2016. 